\section{TAIWAN TEMPORARY WORKERS AND LABOR MARGINALIZATION IN THE CONTEXT OF SEGMENTED LABOR MARKET, 1991-2010}

\author{
Ji-Ping Lin \\ Research Center for Humanities and Social Sciences \\ Academia Sinica \\ jplin@sinica.edu.tw
}

\begin{abstract}
Cómo citar este artículo/Citation: Lin, J-P. (2016). "Taiwan Temporary Workers and Labor Marginalization in the Context of Segmented Labor Market, 1991-2010". Arbor, 192 (777): a291. doi: http://dx.doi.org/10.3989/arbor.2016.777n1007
\end{abstract}

Received: September 12th, 2013. Accepted: October 31st, 2014.

ABSTRACT: From the perspective of segmented labor market theory, this paper aims to provide evidence-based study on temporary workers and labor marginalization in Taiwan in the period of 1991-2010. New phase of industrial restructuring and monopsony dating back to the early 1990 s serves as the main force in shaping Taiwan labor market which is characterized by new type of segmented labor market. The paper demonstrates (1) temporary workers in general and foreign contract workers in specific, and (2) status of labor marginalization by using composite indicator derived from wage gains and working load. Main findings are: (1) because of deindustrialization, manufacturing offshoring, and new business monopsony, temporary workers including foreign contract workers and lowworkload low-pay workers are surging, being mostly selective of females, the youth, the less educated, and workers in traditional manufacturing and electronics; (2) in specific, based on existing research, the paper characterizes the interaction of immigrant contract workers with Taiwan native-born workers. The paper concludes that entrapped temporary workers and labor marginalization are polarizing Taiwan labor market and growing foreign contract workers who are entrapped in secondary labor market too are associated with enhancing labor market segmentation effect. Tensions surge sharply in secondary labor market and feelings of relative deprivation among workers in secondary labor market rise sharply. Thus profound and insightful institutional changes in labor market are urgently required.

KEYWORDS: foreign contract workers; labor marginalization; segmented labor market; Taiwan; temporary workers.

\section{TRABAJADORES TEMPOREROS DE TAIWAN Y MARGINACIÓN LABORAL EN EL CONTEXTO DEL MERCADO DE TRABAJO SEGMENTADO, 1991-2010}

Copyright: (C) 2016 CSIC. This is an open-access article distributed under the terms of the Creative Commons Attribution-Non Commercial (by-nc) Spain 3.0 License

RESUMEN: El objetivo de este artículo es analizar, desde la perspectiva de la teoría del mercado de trabajo segmentado, el proceso de marginalización de los trabajadores temporales en Taiwán en el período 1991-2010. La reestructuración industrial y el monopolio comercial experimentado durante la década de los noventa han moldeado el mercado de trabajo taiwanés que se caracteriza por nuevas formas de segmentación. Este artículo analiza las formas de marginalización de los trabajadores temporales en general, y de los trabajadores migrantes temporales en particular, a través del uso de indicadores. Las principales conclusiones del artículo son que, como consecuencia de los procesos de desindustrialización y externalización de la economía y de las nuevas formas de monopolio comercial, se ha producido un considerable incremento en el mercado de trabajo taiwanés de los trabajadores temporales -incluidos trabajadores temporales migrantes reclutados a través de programas- con especial incidencia en el caso de las mujeres, los jóvenes y los trabajadores de baja cualificación y en los sectores tradicionales de la manufactura y la electrónica. El artículo también caracteriza la interacción entre los trabajadores taiwaneses y los trabajadores inmigrantes temporales reclutados a través de programas. El artículo concluye que las formas de temporalidad y de marginalización laboral que experimentan este tipo de trabajadores muestran la polarización del mercado de trabajo taiwanés y realzan el efecto de segmentación. El surgimiento de sentimientos de «privación relativa entre este tipo de trabajadores muestran la urgencia de abordar cambios institucionales en el ámbito laboral.

PALABRAS CLAVE: Trabajadores extranjeros; marginalización laboral; mercado de trabajo segmentado; Taiwán; trabajadores temporales. 


\section{INTRODUCTION}

The main theme of this paper is Taiwan's temporary workers, with a particular emphasis on the dynamic change of worker marginalization status during the period of 1991-2010. Looking back at Taiwan past longterm labor market development trajectory, segmented labor markets (hereafter SLM) turns out to fit the Taiwanese case. This research aims to (1) characterize temporary workers and labor marginalization and (2) to explain the underlying mechanism using SLM in the context of Taiwan labor market in 1991-2010. The number of temporary workers is seen to grow in an unprecedented pace since the middle 1990s. The research thus applies SLM as main theoretical ground to account for temporary work and labor marginalization in the context of Taiwan's labor market.

SLM aims to explain the economic marginalization of the labor force, particularly racial minorities, lowskilled immigrants, native-born workforce with lower social class, and female workers. SLM appeared in the early 1970s (e.g. see Doeringer and Piore, 1971, Reich and Gordon and Edwards, 1973; Gordon and Edwards and Reich, 1982), with an initial motivation to explain persistent inequalities in the U.S. labor market, especially those observed by gender, race/ethnicity, and social class. As such, SLM emphasizes the existence of distinct and separate labor markets, primary labor market and secondary labor market. SLM also classifies jobs by "good" and "bad" jobs. Primary labor market is characterized by good jobs with high wage gains, permanent work, promising career promotion, much better benefits, high employment security, and thus very low turnover, as opposed to secondary labor market in which jobs are characterized by low pays, temporary and casual work, little advancement of job promotion, low employment security, and high turnover.

Another important feature of SLM is the lack of labor mobility between both segments of labor market in the sense that workers in secondary labor market encounter substantial barriers to move from secondary to primary labor market. Lack of work mobility from second labor market upward to primary labor market serves as a main cause of the formation of social hierarchy and stagnation of social mobility. Thus temporary workers tend to cycle between jobs in secondary labor market and being unemployed and to move inand out of the labor force frequently (see Reich, 2009).

Empirical studies suggest that since the 1980s, the dimensions of SLM have evolved in the United States, European countries, Japan, as well as some eastern
Asian countries. Although some racial and gender segmentations were shrinking, new sources were emerging to account for new segmented labor market (Taubman and Wachter, 1986). These consists of segmentation between stable number of workers with secure jobs and growing long-term unemployed labor force who are characterized mostly by the young in Europe, but the middle-age unemployed workforce in Japan and some eastern Asian countries. Another noteworthy dimension involved a distinction between fixed-term contract workers and indefinite contract workers. Such new development in employment relation leads to regular versus non-regular segmented labor market in Japan and permanent versus temporary segmented labor market in Taiwan. Another noteworthy feature is that in light of fast fadeout in the demand of middle-level jobs but quick surge in demand for high-level jobs, with native-born workers being unwilling to take low-level jobs, immigration is triggered to fill the vacancy of low-level jobs in host society (Sassen, 1990). Thus the distinction between low-skilled immigrant and native-born workers becomes a distinguishing new segmentation in the labor market.

In addition to the aforementioned new developments, changing demographic composition of the labor force, market conditions, and institutional forces drive employers to call for more flexibility in employment to enhance market efficiency. Calls for employment flexibility have gained many advocates and adherents in the late 1990s and become prevalent in early $21^{\text {st }}$ century. They became gradually accepted and gained numerous adherents in the world in the 1990s, which marked as an important era that policy measures aiming to promote labor market flexibility became a worldwide consensus and various policy actions were launched. Employment flexibility has its advantages, but its fruits are selective of a few classes of workers such as those with permanent and highpay jobs. On the other hand, increasing number of workers who are disadvantaged to such development trend are seen to fall entrapped as temporary workers within inferior working conditions. Temporary workers in the labor market are workers who are characterized by being entrapped in segmented labor market and being marginalized in working conditions such as wage gains, leisure time, welfare, etc.

Parallel to the implementation of flexibility is the increasing power of monopsony among employers (Manning, 2003). But stressing only on dimension of employment flexibility while ignoring employment security is like that of driving a car equipped with only 
gas pedal but without any brake. Such developments in flexibility and monopsony lead to another new dimensions in shaping new labor market segmentation. However, such development, particularly the strong monopsony effect in the secondary labor market, has been subject to many critical criticisms due to widening earnings inequality, earnings volatility, stagnation of labor industrial and social and geographical mobility (Brown, Haltiwanger, and Lane, 2006; Osberg et al., 1986). When outcries and angers from workers in the secondary labor market are so strong nowadays, emphasis on employment stability in the secondary labor market becomes top priority for sustainable employment relations (Auer and Cazes, 2003).

SLM helps to explain labor marginalization from many perspectives and dimensions. Nevertheless, one dimension that is worthy of stressing but draws less attention is cultural perspective. For example, Bauder (2001) makes an excellent review on SLM and develops arguments from the perspective of cultural and human geography to integrate SLM with cultural geography. Explanations from cultural and geographical perspective extend the power of SLM in accounting for spatial divisions of the labor force in the labor market as an accessibility issue and why segmented jobs are unevenly allocated in space.

Following the logics of past theoretical development in SLM, it becomes easy to understand the issues associated with temporary employment and potential impacts of labor marginalization on an economy and a society. In the very beginning of the $21^{\text {st }}$ century, scholars have repeatedly reminded of policymakers about the costs of ignoring surging temporary employment and labor marginalization. Many empirical researches have suggested that temporary employment is not only associated with individual short-run and long-run wage losses, but also tends to be associated with personal downward career mobility and degradation of socio-economic status. As opposed to the so-called standard employment which is on the full-time and continuing contract basis, temporary employment belongs to non-standard employment which is a collective term for such employment arrangements like "casual employment", "contingent employment", "precarious employment", "non-permanent employment", "on-call work", "atypical employment", "part-time work", "fixed-term work", or "marginal employment", etc. (Lin, 2013a).

A number of researches on temporary employment focus on individual behavioral response to work stress, attitudes of organizational commitment, per- ception of well-being and equality, psychological behavior among temporary workers (e.g. Feldman, Doerpinghaus, Tumley, 1994; De Wile, 2005; De Cuyper et al., 2008). In short, marginalization, insecurity, and instability are the most important characteristics of temporary employment. As a result, contemporary policy measures designed for mitigation of adverse consequences associated with temporary employment center around the pivot of constructing economic security and employment stability.

The following section introduces temporary workers of Taiwan nationals and labor marginalization in general, and highlights long-term marginalized status of Taiwan indigenous peoples (TIPs hereafter) in specific. Since early 1990s, Taiwan opened domestic labor market to foreign contract workers who mostly are temporary workers in the secondary labor market. The paper also introduces the role of foreign workers and subsequent impact of immigration on Taiwan labor market. The following part explores ordinary Taiwan temporary workers in general and workers of Taiwan indigenous peoples and foreign contract workers in specific.

\section{CONTEXT OF RESEARCH BACKGROUND: TAIWAN LABOR MARKET IN 1991-2010}

Taiwan's labor market conditions and labor relations were mainly shaped by political regime before the year of 1990. Under Japanese jurisdiction during 1895-1945 and KMT (Kuomintang, or Chinese Nationalist Party) ${ }^{1}$ rule during 1945 to the early 1990s, the population and domestic labor market of Taiwan were closed to world systems for a century. After World War II and until the late 1980s, Taiwanese development continued to be largely dependent on internal forces, although external influences, mostly from the United States and partly from China in terms of politics and Japan in terms of economics, remained crucial.

Between 1961 and 1973, rapid economic growth generated a massive rural-to-urban migration, especially migration to the northern and southern areas of the country. Despite the net loss of rural human resources, large remittances sent back by migrants in urban areas helped prevent the decline of the rural economic base and social order. In contrast to many other developing countries, massive urbanization did not result in extensive rural poverty and serious unemployment in urban areas. The oil shocks of 1974 and 1979 and increasing competition from other developing countries forced Taiwan to switch to the development of high-tech industries. The most important was the establishment of a science park in 
Hsinchu City in 1980, which is now known as Taiwan's Silicon Valley. The late 1980s marked a key era of migration transition, both internally and internationally, as the impact of economic restructuring, burgeoning globalization, and political liberalization became apparent. As a result of a shift away from manufacturing to service industry and the increasing economic dominance of northern Taiwan, regional migration came to be characterized by a net transfer northward from the other regions (Lin, 2005 and 2012).

It is worthy of emphasizing that the era of late 1980s and early 1990s serves as a crucial period of political democratization and economic liberalization, with movements toward pluralistic society and culture. One salient outcome of such developments was the formation of new dimensions of labor market segmentation. Taiwanese labor market started experiencing drastic changes since the first half decade of the 1990s. The most salient transition could be attributed to declining job security and pervasive and persistent disturbance of working conditions. For example, soaring unemployment and the corresponding socioeconomic problems have become a nation-wide issue among the ordinary people and policy concerns in the government since the year of 1996. On the other hand, parallel to the problem of unemployment in Taiwan is the issues associated with job security, involuntary turnover and the succeeding adjustment of workers in the labor market.

As a result of deindustrialization, manufacturing offshoring, and dwindling job security, emergence of temporary employment, increasing temporary workers, stagnation of wage gains growth, and involuntary turnover issues have gained much attention from the public (Lin, 2007). One noteworthy feature in segmented labor market is that workers in secondary labor market encounter barriers to move upward to primary labor market and often circle between employment and unemployment and finally tend to move in and out of the labor force frequently. Based on information derived from record-linkage data, this feature is confirmed by the study on migration of Taiwan unemployed labor (Lin and Liaw, 2011). Another feature about job "lock down" of marginal labor is also confirmed by a research using linked data of national health insurance data and household registration data (Lin 2008).

In specific, although not included in empirical analysis of the paper, it is worthy of highlighting Taiwan indigenous peoples (TIPS) who serve as long-term marginalized labor in Taiwan labor market. TIPs belong to the branch of the Austronesian peoples (Blust, 1985; Li, 2011).
Since the early $17^{\text {th }}$ century, TIPs underwent economic competition, armed conflicts, cultural assimilation, and political suppression with a series of colonizing peoples, including Chinese, Dutchmen, and Japanese. All of these led to the decline of TIPs population for the past three centuries. ${ }^{2}$ Similar to other countries' ethnic minority population, contemporary TIPs in Taiwan are associated with lower socioeconomic status, much shorter life expectancy, more disadvantaged labor market outcomes such as income gains and employment, etc.

The perspectives of cultural geography and SLM help explain spatial segregation of TIPs in labor market and residential pattern. Based on the author previous co-authored studies on the internal migration of TIPS (Chang, Lin, and Liu, 2010), TIPs are characterized by four features in terms of population distribution and migration: (1) geographically segregated population distribution, (2) very migratory and mostly rural-tourban migration, (3) periphery of metropolitan areas serving as main destination choice for TIPs rural-tourban migrants; (4) weak ability of TIPs migrants to make onward migration and mostly choose return migration, once repeat migration occurs. Such situations raise question like: if migration serves as an effective means in promoting individual SES and thus in enhancing integration in the long run, then how can we explain a phenomenon that TIPs have persistently been associated with much lower SES than non-TIPS which apparently counters a widely accepted wisdom by migration scholars? Such persistent segregation in labor market and housing becomes evident from the perspective of SLM and cultural geography. It is mainly due to many barriers that disallow TIPs to move into primary labor market and the weak embedded social network of TIPs with other ethnic groups. Such situation, particularly notable in the older TIPs cohorts, can be attributed in part to language proficiency of using main stream language in Taiwan society to communite with other ethnic groups (Liu et al., 2015).

In short, the era of the 1990s marked as the onset of new labor market segmentation that shapes contemporary labor market conditions in Taiwan, and the years after 2000 as the era in which issues associated fast growing temporary workers and labor marginalization start becoming noteworthy, including issues about wage growth stagnation, increasing incomes inequality, disappearance of the middle class and surging poverty, job security and stability, social mobility, youth unemployment, etc. The remaining sections present situations of native-born temporary workers and labor marginalization based on micro data sets. 


\section{CHARACTERIZATION OF TEMPORARY WORKERS} AND LABOR MARGINALIZATION

\section{Indicator Definition of labor marginalization}

From the perspectives of segmented labor markets, workers in primary and secondary labor markets are associated with huge differences in working conditions and individual well-being, such as wage level, workload, career advancement, welfare benefits, etc. Moreover, another distinctive difference between workers of primary and secondary labor markets is a feature regarding what individuals are able to do. As such, workers in primary labor market are highly independent, whereas those in secondary labor market tend to be subordinate. According to Amartya Sen's research (Sen, 2004), central to individual well-being is "beings" and "doings". Sen's approach suggests traditional indicators of well-being like individual/house income and national wealth is not directly important. Thus, the amount of resources available to an individual is central to reflect individual well-being.
To characterize primary and secondary labor markets, the research proposes a simple method of constructing a composite index on the basis of two factors to reflect both working conditions and individual well-being. They consists of (1) workload serving as the proxy for work input and individual "doings", and (2) wage gains serving as the proxy for work output and "being".

Given that the temporary workers by definition may not simply be identified by their workload level or workload, the present study adopts a simple classification to illustrate the marginalization status of Taiwan's temporary workers. Based on workload and wage pay, individual workers are classified into four categories (Figure 1): (1) High workload-High wage pay (HW-HP), (2) Low workload-High wage pay (LWHP), (3) Low workload-Low wage pay (LW-LP), and (4) High workload-Low wage pay (HW-LP). HW and LW refer to the category for above-average workload and below-average workload, respectively. Similarly, HP and LP refer to the category for above-average wage pay and below-average wage pay, respectively.

Figure 1. Category of Worker Status by Workload and Wage Pay

\section{Wage Pay}

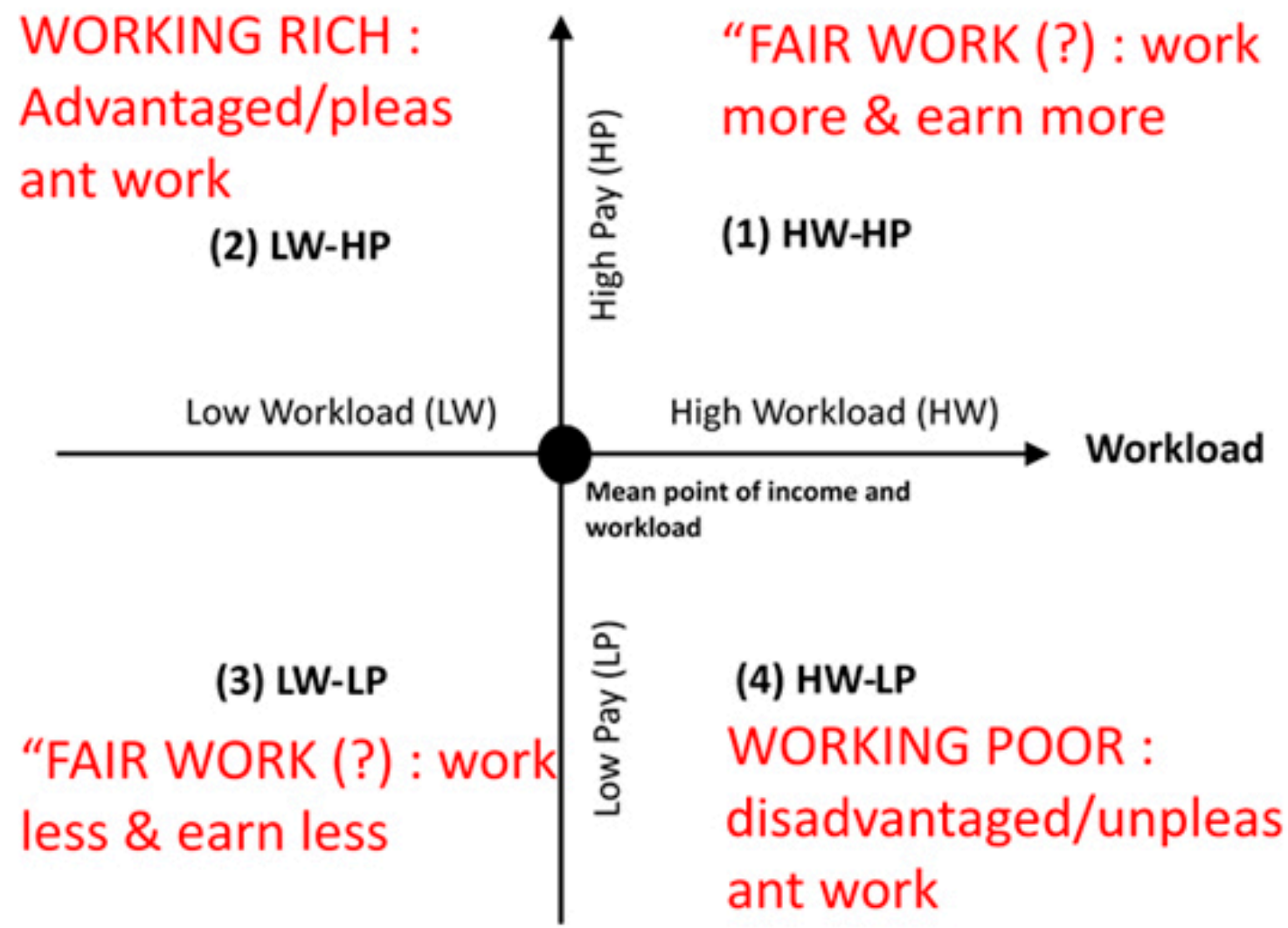


Based on the aforementioned definition, all qualified respondents in the research are specified their individual status of worker marginalization. It is determined by making comparison of individual wage income and individual weekly hours of work recorded with average wage income and average weekly hours of work computed from each Manpower Utilization Survey (MUS thereafter) of a specific year. In this manner, there is no doubt that workers belonging to the LW-HP category are those of the most advantaged workers, but those belonging to the HW-LP category are the least advantaged workers with the least favorable position in the labor market.

\section{Data}

The research utilizes micro data sets to characterize temporary workers and labor marginalization, mainly based on the 1991-2010 MUSs. The MUSs are well established large-scale surveys conducted by the Taiwan Census Bureau in May of each year since 1978. The population in study under the survey framework of MUSs are those aged 15 and over, with a sampling ratio of around 0.4 percent. Each MUS of 1991-2010 comprises more than 60,000 individuals and records rich in individual information on demographic characteristics, human capital, socioeconomic status, labor market participation and work experience, place of work and residence, labor mobility and job turnover, wage, etc.

The research excludes those not in the labor force and the unemployed. In addition, military sub-samples are excluded. Thereafter the 1991-2010 MUSs are pooled together and the qualified respondents in the pooled data amount to more than $1,190,000$ in number. All original weights corresponding to each qualified respondent are taken into account in research computing and analysis. It is worthy of emphasizing that because these surveys belong to the May-round supplements of Human Resources Surveys (HRSs) which are essentially similar to the American Current Population Surveys (CPSs) or Canadian Labor Force Surveys (LFSs) in terms of surveyed population, questionnaire design, and design and framework of sampling. Thus, research results are internationally comparable to a large extent.

The study synthesizes the following variables in MUSs to characterize temporary workers: gender, educational level, age, wage income, workload, and worker status. The study is interested in the labor market measured by industry. Industry information recorded in MUSs is based on Taiwan Standard Industry Classification (SIC) which follows the framework of ILO International Standard Industrial Classification (ISIC). Because SIC changes with each newly revised ISIC, the research standardizes various versions of SIC applied in different MUSs by the following categories of industry: (1) agriculture, (2) mining, (3) light industry, (4) machinery, (5) petrochemicals, (6) electric and electronic industry, (7) public utilities, (8) construction, (9) commerce, (10) transportation, (11) finance, banking, and insurance, (12) commercial service, and (13) social and personal service.

\section{Empirical evidences}

In the past two decades, the composition and average monthly wage income of Taiwanese workers have changed in a systematic way for different types of worker. On the basis of differentiated worker status, Table 1 demonstrates volume of workers and changes in terms of share and average monthly wage income (in USD) of workers in 1991-2010. The worker status consists of four categories, including, employers, the self-employed, government employees, private employees, and unpaid family workers.

Table 1 indicates a steady growth in worker volume during the past two decades, growing from 8.54 million in 1991 to 10.95 million in 2010, with an average yearly growth rate of about 1.41 percent. It is worthy of highlighting that MUSs do not include foreign labor, foreign contract workers are not taken into account in Table 1. In early 1990s, Taiwan opened its labor market to foreign contract workers with a volume of only several thousands in 1992 but grew up to about 460 thousands in 2010. By the end of 2010, foreign contract workers constituted about 4.2 percent of the whole population of Taiwan workers.

It is interesting to see a systematically changing pattern of workers in terms of the composition of worker status over time. Table 1 exhibits several clear patterns in the past two decades: (1) a slight decline in the share of employers; (2) a significant decline in the share of the self-employed; (3) a very slight decrease of government employees; (4) a very substantial increase in the share of private employees; and (5) a notable decline in the share of unpaid family workers. For examples, the share of the self-employed workers drops from 18.6 percent in 1991 to 12.4 percent in 2010; the corresponding share for the private employees however increases sharply from 56.2 percent in 1991 to 68.0 percent in 2010. The changing structure of the worker status reflects restructuring of the socioeconomic/political systems and the institutional changes in Taiwan over the past twenty years. 
Table 1. Volume of Workers and Share of Workers by Worker Status, 1991-2010

\begin{tabular}{|c|c|c|c|c|c|c|c|}
\hline \multirow{3}{*}{ Year } & \multirow{3}{*}{$\begin{array}{l}\text { Volume of } \\
\text { Workers } \\
\text { (millions) }\end{array}$} & \multicolumn{6}{|c|}{ Share of Workers by Worker Status (\%) } \\
\hline & & \multirow[b]{2}{*}{ Overall } & \multicolumn{5}{|c|}{ Worker Status } \\
\hline & & & Employer & $\begin{array}{l}\text { The Self- } \\
\text { Employed }\end{array}$ & $\begin{array}{c}\text { Govr. } \\
\text { Employee }\end{array}$ & $\begin{array}{l}\text { Private } \\
\text { Employee }\end{array}$ & $\begin{array}{c}\text { Unpaid Family } \\
\text { Worker }\end{array}$ \\
\hline 1991 & 8,54 & 100,0 & 5,0 & 18,6 & 10,7 & 56,2 & 9,4 \\
\hline 1992 & 8,68 & 100,0 & 5,1 & 18,4 & 11,2 & 56,6 & 8,8 \\
\hline 1993 & 8,80 & 100,0 & 5,2 & 17,6 & 11,6 & 57,1 & 8,6 \\
\hline 1994 & 8,98 & 100,0 & 5,2 & 17,2 & 11,0 & 57,9 & 8,6 \\
\hline 1995 & 9,14 & 100,0 & 5,3 & 16,8 & 10,7 & 58,7 & 8,5 \\
\hline 1996 & 9,25 & 100,0 & 5,3 & 16,7 & 11,2 & 58,2 & 8,6 \\
\hline 1997 & 9,34 & 100,0 & 5,4 & 16,3 & 11,1 & 59,2 & 8,0 \\
\hline 1998 & 9,47 & 100,0 & 5,5 & 15,7 & 10,4 & 60,8 & 7,6 \\
\hline 1999 & 9,58 & 100,0 & 5,4 & 16,1 & 10,0 & 60,8 & 7,8 \\
\hline 2000 & 9,71 & 100,0 & 5,4 & 15,7 & 9,9 & 61,5 & 7,5 \\
\hline 2001 & 9,70 & 100,0 & 5,1 & 15,5 & 10,0 & 62,5 & 7,0 \\
\hline 2002 & 9,90 & 100,0 & 5,1 & 15,5 & 9,5 & 62,6 & 7,2 \\
\hline 2003 & 9,97 & 100,0 & 5,1 & 15,2 & 9,9 & 62,8 & 7,1 \\
\hline 2004 & 10,15 & 100,0 & 5,1 & 14,5 & 10,1 & 63,4 & 6,9 \\
\hline 2005 & 10,28 & 100,0 & 4,9 & 14,2 & 9,6 & 64,7 & 6,6 \\
\hline 2006 & 10,40 & 100,0 & 5,0 & 13,7 & 9,0 & 66,1 & 6,3 \\
\hline 2007 & 10,60 & 100,0 & 5,0 & 13,3 & 8,9 & 66,8 & 6,1 \\
\hline 2008 & 10,76 & 100,0 & 4,8 & 12,9 & 9,1 & 67,4 & 5,9 \\
\hline 2009 & 10,79 & 100,0 & 4,4 & 12,5 & 9,9 & 67,8 & 5,5 \\
\hline 2010 & 10,95 & 100,0 & 4,4 & 12,4 & 9,9 & 68,0 & 5,4 \\
\hline
\end{tabular}

Source: compiled by the author from the source data of Taiwan Human Resources Surveys

Table 2 demonstrates different changing patterns of wage income among workers with different worker status. The top panel of Table 2 aims to demonstrate average monthly wage income by worker status with respect to each year in the period from 1991 through 2010. As expected, the employers' wage is much higher than the average monthly wage income and private employee much lower than the average month wage income, while those associated with the selfemployed and the government employees have their wage income around the average level. It is worthy of note that the government employees had their wage below the average in the 1990s, but their wage has been raised to a level higher than the average since.

The second panel of Table 2 shows a pattern of wage income growth for the four types of workers though their growth rates are not all the same. Their differences are stated as follows: (1) the employers and the self-employed are seen to have a substantial growth in their wage income; (2) the government employees are associated with a moderate growth of wage income; and (3) the private employees have the lowest growth of wage income in the past two decades. For example, during the past two decades in terms of whole wage income growth, the employers and the self-employed are associated with a growth of 39.5\% percent and 11.7 percent, respectively, during 1991-1995, and the private employees have a similar high growth rate of 10.5 percent in the same period. Nevertheless, the growth of wage income lost its momentum since the second half of the 1990s, while the private employees had the least growth in wage income which is particularly noteworthy in 2006-2010.

We now turn to demonstrate changing patterns of average weekly work hours (left panel of Table 3) and average hourly wage pay for each year in the period of 1991-2010 (right panel of Table 3). In terms of the workers' workload, the left panel of Table 3 suggests that there is no significant change in the past two decades. The average weekly work hours have changed from 49.4 hours in 1991 to 46.0 hours in 2010, but such a change is very minor as a whole. 
Table 2. Average Monthly Wage Income by Worker Status, 1991-2010

\begin{tabular}{|c|c|c|c|c|c|c|}
\hline \multirow[b]{2}{*}{ Year } & \multirow[b]{2}{*}{ Average } & \multicolumn{5}{|c|}{ Worker Status } \\
\hline & & Employer & $\begin{array}{l}\text { The Self- } \\
\text { Employed }\end{array}$ & Govr. Employee & Private Employee & $\begin{array}{l}\text { Unpaid } \\
\text { Family } \\
\text { Worker }\end{array}$ \\
\hline \multicolumn{7}{|c|}{ Monthly Wage (USD) } \\
\hline 1991 & $1,230(0.00)^{*}$ & $2,536(1.06)$ & $1,325(0.08)$ & $1,271(0.03)$ & $936(-0.24)$ & - \\
\hline 1992 & $1,739(0.00)$ & $5,619(2.23)$ & $1,551(-0.11)$ & $1,450(-0.17)$ & $1,112(-0.36)$ & - \\
\hline 1993 & $1,928(0.00)$ & $6,682(2.47)$ & $1,542(-0.20)$ & $1,524(-0.21)$ & $1,220(-0.37)$ & - \\
\hline 1994 & $1,830(0.00)$ & $5,669(2.10)$ & $1,658(-0.09)$ & $1,593(-0.13)$ & $1,251(-0.32)$ & - \\
\hline 1995 & $2,211(0.00)$ & $7,530(2.41)$ & $2,035(-0.08)$ & $1,637(-0.26)$ & $1,388(-0.37)$ & - \\
\hline 1996 & $1,863(0.00)$ & 4,596 (1.47) & $1,912(0.03)$ & $1,700(-0.09)$ & $1,387(-0.26)$ & - \\
\hline 1997 & $1,736(0.00)$ & $3,878(1.23)$ & $1,783(0.03)$ & $1,692(-0.03)$ & $1,336(-0.23)$ & - \\
\hline 1998 & $1,672(0.00)$ & $4,247(1.54)$ & $1,579(-0.06)$ & $1,498(-0.10)$ & $1,235(-0.26)$ & - \\
\hline 1999 & $1,786(0.00)$ & $3,304(0.85)$ & $2,613(0.46)$ & $1,597(-0.11)$ & $1,296(-0.27)$ & - \\
\hline 2000 & $1,606(0.00)$ & $3,425(1.13)$ & $1,554(-0.03)$ & $1,683(0.05)$ & $1,290(-0.20)$ & - \\
\hline 2001 & $1,534(0.00)$ & $3,774(1.46)$ & $1,578(0.03)$ & $1,565(0.02)$ & $1,140(-0.26)$ & - \\
\hline 2002 & $1,353(0.00)$ & $2,866(1.12)$ & $1,248(-0.08)$ & $1,483(0.10)$ & $1,114(-0.18)$ & - \\
\hline 2003 & $1,369(0.00)$ & $2,697(0.97)$ & $1,208(-0.12)$ & $1,551(0.13)$ & $1,151(-0.16)$ & - \\
\hline 2004 & $1,561(0.00)$ & $3,820(1.45)$ & $1,395(-0.11)$ & $1,604(0.03)$ & $1,215(-0.22)$ & - \\
\hline 2005 & $1,635(0.00)$ & $3,459(1.12)$ & $1,586(-0.03)$ & $1,922(0.18)$ & $1,294(-0.21)$ & - \\
\hline 2006 & $1,531(0.00)$ & $3,244(1.12)$ & $1,445(-0.06)$ & $1,619(0.06)$ & $1,269(-0.17)$ & - \\
\hline 2007 & $1,616(0.00)$ & $3,935(1.44)$ & $1,507(-0.07)$ & $1,670(0.03)$ & $1,281(-0.21)$ & - \\
\hline 2008 & $1,634(0.00)$ & $3,734(1.29)$ & $1,609(-0.02)$ & $1,775(0.09)$ & $1,311(-0.20)$ & - \\
\hline 2009 & $1,535(0.00)$ & $3,526(1.30)$ & $1,658(0.08)$ & $1,645(0.07)$ & $1,204(-0.22)$ & - \\
\hline 2010 & $1,788(0.00)$ & $4,582(1.56)$ & $2,310(0.29)$ & $1,713(-0.04)$ & $1,281(-0.28)$ & - \\
\hline \multicolumn{7}{|c|}{ Average Yearly Growth (\%) } \\
\hline 1991-1995 & 17,0 & 39,5 & 11,7 & 6,6 & 10,5 & - \\
\hline $1996-2000$ & $-3,4$ & $-6,2$ & 1,7 & 0,0 & $-1,7$ & - \\
\hline 2001-2005 & 2,0 & 0,6 & 1,3 & 5,6 & 3,3 & - \\
\hline $2006-2010$ & 4,3 & 10,1 & 13,4 & 1,6 & 0,4 & - \\
\hline
\end{tabular}

Source: see Table 1

*ratio of difference from the average divided by the average.

By examining the corresponding figures by worker status, the employers and the self-employed workers have the highest weekly work hours. In addition, the patterns of weekly work hours for the two types of the employers and the self-employed are rather similar. The unpaid family workers and the private employees have the second highest workload, with that of the unpaid family workers being higher than that of the private employees. As expected, the government employees have the lowest workload in comparison to other types of workers. This is mainly because the government employees in Taiwan have certain influences upon building the related administrative laws due to their administrative power.

The right panel of Table 3 aims to demonstrate average hourly wage pay with respect to different types of workers. As expected, the average hourly wage pay fluctuates in accordance with Taiwan's business cycle, but it exhibits a slight declining trend in general during 1991-2010. The average hourly wage pay by worker status suggests that the employers as expected have the highest average hourly wage. Main- 


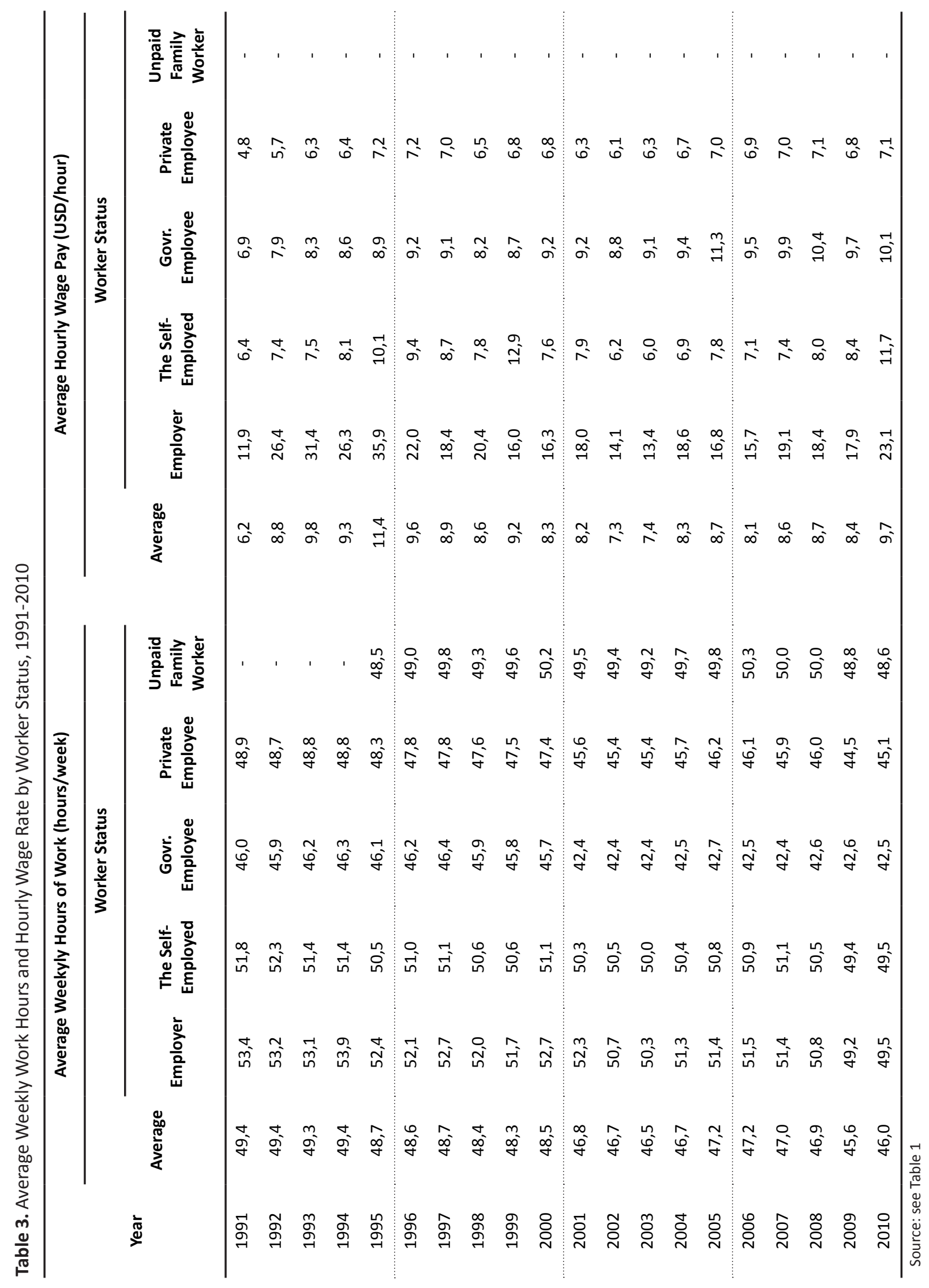


ly because of having the lowest average workload, the government employees have the second highest average hourly wage in general. This situation almost holds during the past two decades. Compared to the private employees, the self-employed workers are associated with a level of average hourly wage, which is slightly higher than that associated with the private employees.

Now we turn to Taiwan's private employees who are subcategorized into a group of workers with huge variations in terms of their demography, human capital, socioeconomic status, and labor market outcomes. Compared to the employers, the self-employed, and the government employees, the private employees are less advantaged in the labor market. It is worthy of stressing that the unpaid family workers share some characteristics with the private employees and tend to be marginalized like some disadvantaged private employees in the labor market. Because they only take up a fairly small portion as a whole, this research thus focuses solely on the marginalization of the private employees.

The results revealed in Table 4 shed some light on the dynamics and systematic changes in terms of worker marginalization status for the private employees during 1991-2010. Notice that foreign contract workers are not counted in the figures of Table 4, although Taiwan started reopening its labor market to international migration in the first years of 1990s. During 1991-2010, the volume of the private employees grows steadily from 4.7 million to 6.7 million, an increase of around 2 million in number. By examining individual information on wage income and workload from the 1991-2010 micro data sets of Taiwan Human Resources Surveys, it is shown that worker marginalization status of the private employees exhibits the four salient systematic patterns as listed below:

First, there is a significant decline for the shares of the HW-HP and HW-LP private employees, falling about 10 percent and 15 percent respectively in the past two decades. Second, the shares for the LW-HP and LW-LP private employees by contrast increase significantly during the comparable period in the past two decades, a rise of about 10 percent and 15 percent respectively. Third, the share for the HW-LP private employees undergoes a sharp, falling from 42 percent in 1991 to 26 percent in 2010. It suggests that their work conditions have been improved substantially, mainly by the aid of upgrading the labor law in Taiwan. Fourth, the share for the LW-HP private employees, however, is seen to increase for about 10 percent in the past two decades. It is worthy of noting that the increasing aggregate share of the LW-HP private employees and that of the LW-LP private employees suggest an ongoing polarization of wages. Additionally, it serves as a main source of uprising feelings of relative social deprivation, both of which in turn have been causing numerous social confrontations in Taiwan.

It is generally accepted that it is "fair" if a worker is willing to work more and thus earn more. Nevertheless, it is very hard in general to conclude whether a worker who is classified as either the HW-HP category or the LW-LP one is a disadvantaged worker and/or in a less favorable labor market position. We intuitively would think that it is equitable for a worker to have more wage gain if $s /$ he works more and vice versa. But many examples suggest that such sort of viewpoint is problematic unless further individual information, such as willingness to increase workload to earn more wage pay, is available.

Information regarding "willingness to increase workload" revealed by the micro data sets suggests that the decrease in HW-HP share and the increase in LW-HP share on Table 4 cannot be explained as a result of willingness decline of the Taiwan private employees for more workload. Rather, these phenomena can be attributed to the shrinkage of job opportunity in Taiwan. For example, manufacturing offshoring in Taiwan results in a huge loss of low-end jobs in the past two decades. It is observed that many low-skilled young workers are LW-LP workers. Although they express strong willingness to increase workload to make more money, it is unfortunate there are not sufficient low-end job opportunities to meet their demand.

Moreover, the fast emergence of internet shopping in recent years has been creating a high demand for courier workers who are required to delivery orders of goods to customers in a very short period of time, say within one day or even within 8 hours. But the pay earned by courier workers depends on the amount of goods they deliver within the required delivery time. Courier workers in Taiwan are HW-HP workers, but many courier workers start suffering from deteriorating health conditions after working for a certain period of work. Their deteriorating health is mainly due to the intensive workload and high psychic pressure from their working requirements. Thus, if their deteriorating health conditions and medical expenses are taken into account as a cost of labor input, their high wage gains are apparently overestimated. 
Table 4. Worker Marginalization Status of Private Employees, 1991-2010

\begin{tabular}{|c|c|c|c|c|c|c|}
\hline \multirow{2}{*}{ Year } & \multirow{2}{*}{$\begin{array}{c}\text { Volume } \\
\text { of Private } \\
\text { Employees } \\
\text { (millions) }\end{array}$} & \multicolumn{5}{|c|}{ Share of Worker Marginalization Status (\%)* } \\
\hline & & Overall & (1) HW-HP & (2) LW-HP & (3) LW-LP & (4)HW-LP \\
\hline 1991 & 4,69 & 100,0 & 30,5 & 11,6 & 16,2 & 41,7 \\
\hline 1992 & 4,80 & 100,0 & 31,7 & 13,6 & 15,0 & 39,6 \\
\hline 1993 & 4,90 & 100,0 & 28,0 & 12,3 & 17,5 & 42,2 \\
\hline 1994 & 5,07 & 100,0 & 31,7 & 14,0 & 16,7 & 37,5 \\
\hline 1995 & 5,14 & 100,0 & 30,7 & 14,5 & 16,4 & 38,4 \\
\hline 1996 & 5,10 & 100,0 & 29,6 & 16,4 & 17,6 & 36,4 \\
\hline 1997 & 5,26 & 100,0 & 31,0 & 17,0 & 16,8 & 35,2 \\
\hline 1998 & 5,51 & 100,0 & 24,6 & 14,5 & 20,7 & 40,2 \\
\hline 1999 & 5,53 & 100,0 & 23,2 & 15,8 & 21,1 & 39,9 \\
\hline 2000 & 5,70 & 100,0 & 23,2 & 17,0 & 21,2 & 38,6 \\
\hline 2001 & 5,66 & 100,0 & 17,8 & 21,8 & 30,9 & 29,5 \\
\hline 2002 & 5,70 & 100,0 & 20,0 & 20,0 & 28,4 & 31,6 \\
\hline 2003 & 5,78 & 100,0 & 18,5 & 20,2 & 30,4 & 30,9 \\
\hline 2004 & 6,03 & 100,0 & 18,5 & 21,3 & 31,2 & 28,9 \\
\hline 2005 & 6,28 & 100,0 & 17,9 & 21,7 & 31,2 & 29,3 \\
\hline 2006 & 6,38 & 100,0 & 18,3 & 23,3 & 30,4 & 28,0 \\
\hline 2007 & 6,57 & 100,0 & 19,6 & 18,8 & 29,7 & 31,8 \\
\hline 2008 & 6,69 & 100,0 & 19,6 & 19,9 & 29,9 & 30,6 \\
\hline 2009 & 6,48 & 100,0 & 17,7 & 21,2 & 35,9 & 25,2 \\
\hline 2010 & 6,68 & 100,0 & 20,2 & 22,3 & 31,2 & 26,3 \\
\hline
\end{tabular}

Source: see Table 1

*HP monthly wage income above average; LP: monthly wage income below average;

HW: weekly hours of work above average; LW: weekly hours of work below average. see Fig 1.

The research finds the share of the LW-LP private employees serves as a good indicator of the marginalized temporary workers in Taiwan. We find that the sharp increase in both the share and volume of the LW-LP private employees related to increase of the marginal labor and the temporary workers. It is consequently worthy of exploring the characteristics of the LW-LP works in Taiwan. Figure 2 aims to demonstrate the share of the LW-LP private employees by gender, education, age, and some selected industries. In terms of education, Figure 2.1 indicates that the private employees with less education are associated with a higher share of the LW-LP workers and it becomes more evident after the year of 2000 . Figure 2.2 demonstrates age differentials in the LW-LP shares, suggesting that the younger private employees are associated with a higher LW-LP share. After the year of 2000 , there is a significant gap between the share of the youngest age group (aged 15-29) and the other age groups (i.e., aged 30-44 and aged 45+).

In terms of gender, Figure 2.3 suggests that the female workers have a much higher share of LW-LP than the male workers in Taiwan. Although the gender gap in the LW-LP shares is seen to shrink before the year of 2000 , the gender gap is observed to keep at a constant level since the millennium year 2000 . Figure 2.4 demonstrates the gap in the LW-LP shares among some selected industries. It indicates that (1) the traditional manufacturing has the lowest LW-LP share before the year of 2000 , but jump sharply after 2001 and soar up in 2010; (2) the electronics shares 
a similar pattern, with the traditional manufacturing becoming the industry having the highest LW-LP share of private employees after 2001 ; (3) the commerce industry and the insurance/banking/financial services have a similar pattern in their LW-LP shares. It is interesting to find that the insurance, banking, and financial services are associated with the highest LW-LP share in the 1990s in general, but change to have the lowest share after 2001.

\section{FOREIGN CONTRACT WORKERS AND THEIR IMPACTS}

This section characterizes foreign contract workers (FCWs) and their impacts based on some existing researches from the perspective of foreign contract workers as new source of labor in secondary labor market. For the sake of economic development since the 1960s, Taiwan did not restrict immigration of ordinary foreigners, mostly professionals and managers, as

Figure 2.1. Percentage Share of LW-LP Private Employees, 1991-2010 by education (source: see Table 1 )

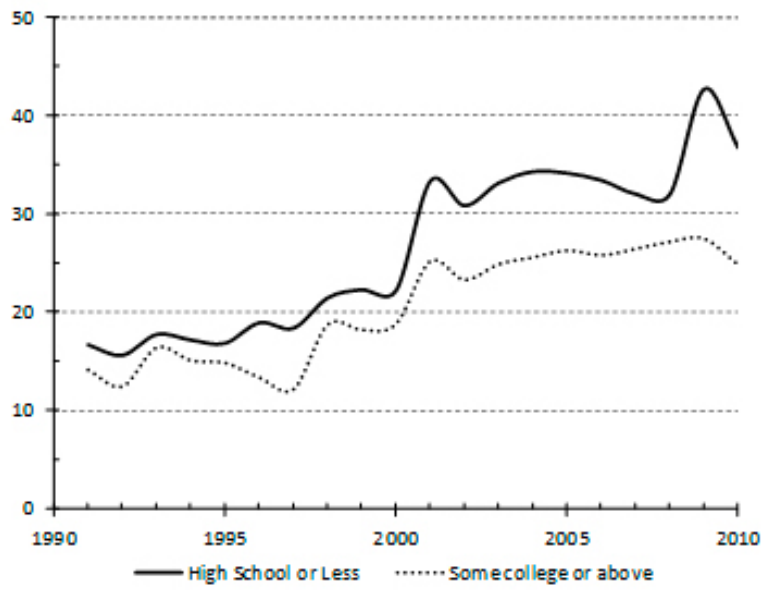

Figure 2.3. Percentage Share of LW-LP Private Employees, 1991-2010 by Gender (source: see Table 1)

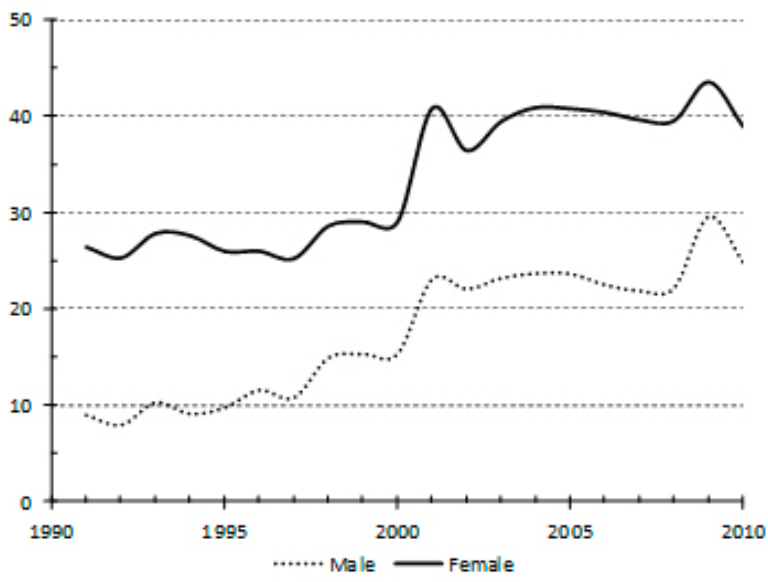

well as their dependents from America and Japan and partly from Europe, but strictly banned low-skilled immigration from other countries. The late 1980s marked a key era of labor market transition, as the impact of economic restructuring, burgeoning globalization, soring wage level, labor shortages, and political liberalization became apparent. Because of the economic boom in the late 1980s that led to the formation of a dual economy (Ranis, 1992), the economy of Taiwan was increasingly hampered by rising wage levels and shortages of native labor in the early 1990s. In response to serious labor shortages, the Taiwanese government decided to open the door to low-skilled immigrants in the 1990s, and subsequent inflows of foreign contract workers from countries of the Association of Southeast Asian Nations (ASEAN) ${ }^{3}$ and foreign wives have begun to serve as a new source of population growth and temporary workers (Liaw, Lin and Liu, 2011; Lin, 2012).

Figure 2.2. Percentage Share of LW-LP Private Employees, 1991-2010 by age (source: see Table 1)

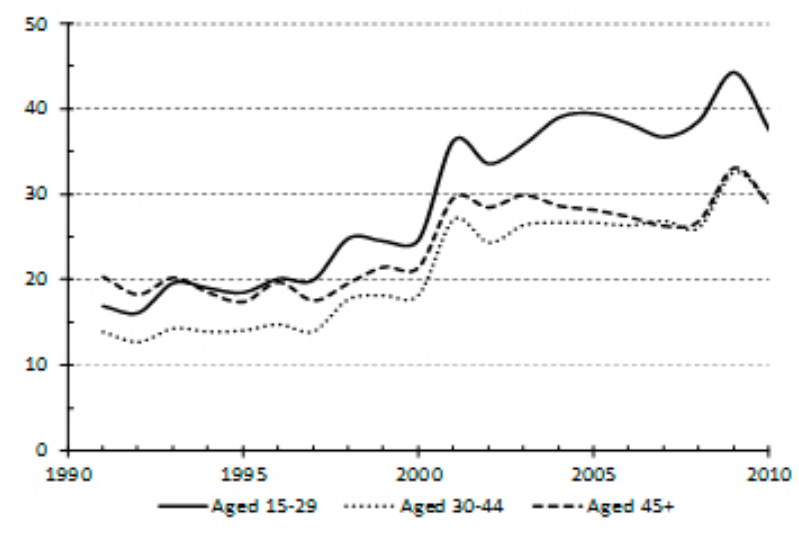

Figure 2.4. Percentage Share of LW-LP Private Employees, 1991-2010 by Industry (source: see Table 1)

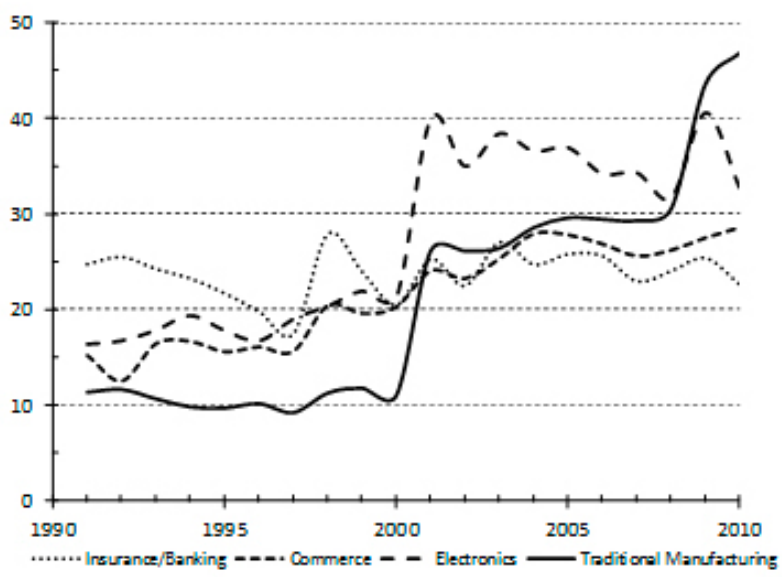


The temporary immigration of foreign contract workers to Taiwan was originally triggered by serious labor shortages that forced the government to open the door to foreign labor in 1992. The period between 1996 and 2000 , however, saw the most noteworthy growth in the population of foreign contract workers, both in terms of overall numbers and the rate of arrival. For example, the total number of FCWs was 15,900 persons in 1992, 236,600 persons in 1996, and 326,500 persons in 2000. As demonstrated by Figure 3, by the end of November 2011, there were 420 thousand foreign contract workers in Taiwan, 222 thousand of whom were employed in the industrial sector and 198 thousand in the services industry as caregivers and home domestic workers. The main sending countries include Indonesia (38 percent of all foreign contract workers), Vietnam (23 percent), the Philippines (19 percent), Thailand (18 percent), and Malaysia (2 percent). By the end of June 2015, FCWs amounts to more than 570 thousand that is around 6 percent of native-born labor force.

The government of Taiwan allows foreign workers to regularize their status of work permit if they migrated with legal work permit and to have worked in
Taiwan for no more than six years at a time. When their work period expires, foreign contract workers are required to return to their home countries where they may apply again for the Taiwan work visas if they choose. These workers are not allowed to become citizens except through marriage to a Taiwanese citizen. It is also worth noting that foreign contract workers are selected from the lower end of income distribution in sending countries and are mostly characterized by low socioeconomic status.

When allowed to immigrate to work in Taiwan, foreign contract workers are paid by Taiwanese employers slighter higher than the legal level of minimum wage. Moreover, it is worthy of stressing that immigration destinations of contract workers were predetermined by their Taiwanese employers before their immigration (Tseng, 2004; Tsai and Tsay, 2004). In other words, low-skilled foreign laborers did not have any privilege to place of work before immigrating into Taiwan. Disallowing foreign contract workers to change employers and thus to choose place of work were subject to very strong criticisms. This regulation was cancelled in 2007 due to the concern of human rights.

Figure 3. Low-skilled Foreign Labor Volume and Share as Taiwan Native-born Labor

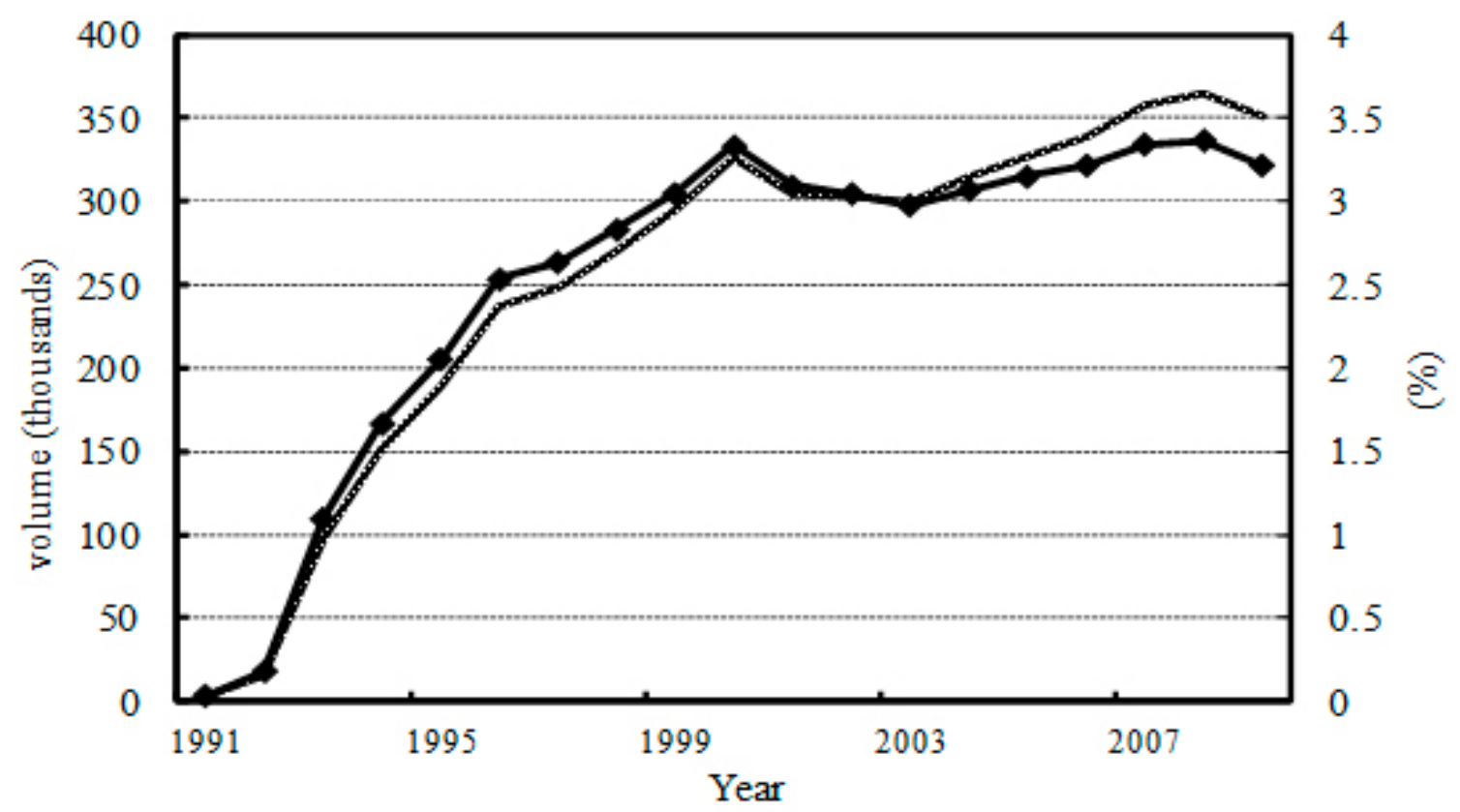

\section{mme ontract foreign labor volume $\quad \sim \%$ as native-born workers}

Sources: Taiwan Annual Report on Human Resources Survey. 1991-2009; Taiwan Annual Report on Labor Statistics. $1991-2009$ 
Figure 4 demonstrates the spatial distribution of foreign contract workers, which suggests that (1) the Taipei metropolitan area in northern Taiwan is characterized by having the highest volume of low-skilled foreign labor and having the highest proportion of places that are categorized as "some" and "significant" immigration intensity within the same area; and (2) Hsinchu area (known as Taiwan's Silicon Valley in the global information and communication technology industry) in northern Taiwan, Taichung, and Kaohsiung metropolitan areas in central and southern Taiwan are classified by having the second highest volume of lowskilled immigrant and the proportion of places' with "some" and "significant" immigrant intensity next to that in Taipei metropolitan area.
Although foreign contract workers are mostly lowskilled laborers, they have made substantial contributions to recent Taiwan's developments in the past twenty years. In terms of labor relations with nativeborn workers within Taiwan labor market, they are found to be complementary to Taiwan's domestic professional and managerial workers on one hand, while playing a competitive role with Taiwan domestic low-skilled workers on the other. In other words, foreign contract workers have generated noteworthy immigration impact on Taiwan labor market. For example, a research by Lin (2013b) on immigration impact analysis helps illuminate the dynamic relationship between domestic manpower redistribution and immigration. Findings of immigration impact on native net migration are consistent with the conventional way of

Figure 4. Spatial distribution of Foreign Contract Workers

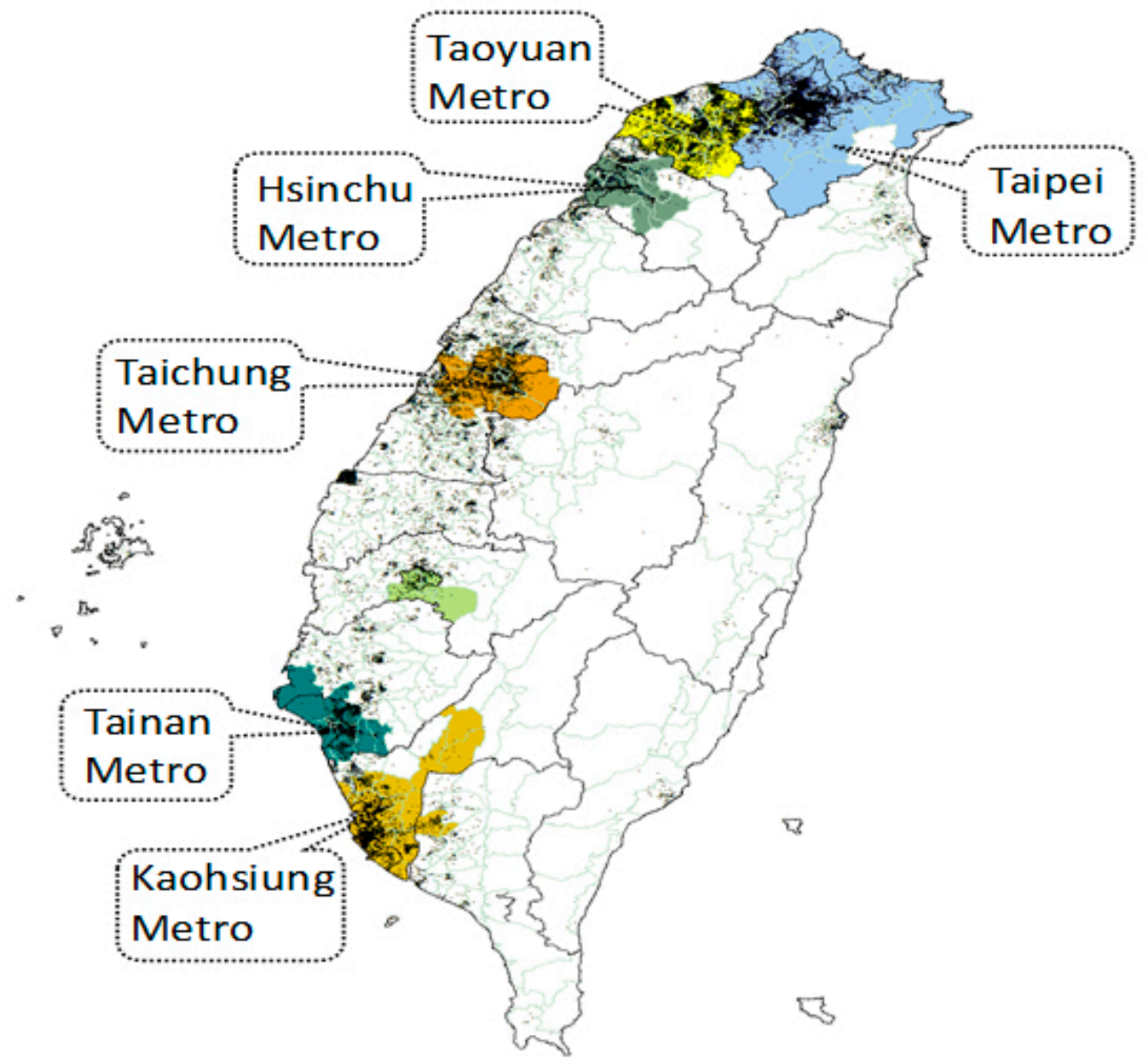

Sources: compiled by the author from micro data of 2000 Taiwan Population Census ( 1 dot=10 persons) 
what we have been used to thinking about, but the underlying mechanisms derived from findings of immigration impact analysis tell us a story that is somewhat different from the conventional wisdom about immigration impact on native migratory responses. Lin (2013b) stresses that we observe a similar pattern of "flights" of native labor, mostly native migrants with less education, from major immigration "port of entry" on both sides of Taiwan and the United States, the underlying forces shaping immigration impact are somewhat different on both settings. For Taiwan, immigration tends to have more impact on native destination choice than on departure decision, which is different from the findings in the United States.

In effect, immigration impact analysis regarding the impact on the net migration of native labor suggests "flights" of native labor are caused by immigration "pushes." But by jointly examining both impacts of immigration on native out-migration and in-migration, the research finds this is not the case in Taiwan. The observed native "flights" from high immigration concentration areas essentially are not mainly triggered by immigration pushing force; instead it mainly resulted from the negative impact of immigration on the in-migration, which outweighs the corresponding negative impact on out-migration for native labor.

In addition to having impact on manpower redistribution of native-born workers, foreign contract workers are seen to be deeply entrapped in secondary labor market. Not only do policy regulations and employers entrap foreign contract workers in Taiwan secondary labor market, but cultural dimension and language proficiency also enhance such entrapping effect on them. As a result, they are associated with more barriers than Taiwan temporary workers, including TIPs, in terms of moving upward to primary labor market. Foreign contract workers who are nearly entrapped in second labor market generate two important labor market outcomes. First, strong entrapment of foreign contract workers within secondary labor market enhances the labor marginalization effect for native-born temporary workers. Both native-born and foreign workers are very competitive in acquiring jobs in secondary labor market. Similar to other countries, it is not surprising to see anti-immigration sentiments among native-born temporary workers. Second, on the other hand, such strong entrapment of foreign contract workers in secondary labor market enhances immigration complementary effect to native-born professionals and the elite. As such, it is natural to see that workers in primary labor market seem "having no opin- ion" about immigration of foreign contact workers and employers are frequently asking the government to increase quota of foreign workers (Lin 2012 and 2013a).

\section{CONCLUSION AND DISCUSSION}

The paper uses segmented labor market theory to explain and characterize temporary labor and labor marginalization in the context of Taiwan. SLM serves as a theoretical grounding, but it does not indicate that SLM is the only theory that can be applied to explain Taiwan labor market. Utilizing simple but straightforward statistic figures, the research has characterized the evolutionary trend of temporary employment and labor marginalization among the private employees in general and foreign contract workers in specific. The paper is an evidence-based research, with a focus more on demonstrating real-world phenomena and their changing trend than on policy-oriented one. The content of the paper thus reads descriptive, but the underlying analyses and cited researches essentially rely heavily on sophisticated data processing, model design, and numerical computing. These are based on a variety of micro data sets, including 1991-2010 Taiwan Manpower Utilization Surveys, 2000 Taiwan Population Census, and 2007 Taiwan Household Registration Data.

The research uses workload as labor input proxy and wage income as labor output indicator, although information on wage income is not measurable for the unpaid family workers. General findings are that during the period of 1991-2010, employers and the self-employed have a substantial growth in wage income, government employees have a moderate wage growth, while the private employees are seen to have the lowest growth in wage gains. The use of indicator for status of labor marginalization further sheds light on the evolutionary trend of labor market conditions and development in the context of Taiwan.

The share for high-workload and low-wage workers is seen to decline substantially, suggesting great improvement in working conditions. Meanwhile, share for low-workload and high-wage workers is also seen to increase noticeably. We further find a significant decline in the share of high-workload and high-wage workers while a salient increase in share for low-workload and low-wage workers. By examining the information on "willingness to increase workload", most low-workload and low-wage workers express strong wish to increase workload to make more wage gain. If workers with characteristics of (1) low-workload and low-wage, (2) strong willingness to work more, but (3) without opportunity to earn more wage income can 
be regarded or/and defined as a marginalized labor, then the aforementioned findings suggest that not only is wage distribution becoming much less equitable, but the phenomenon of labor marginalization, mostly selective of females, the youth, the less educated, and workers in traditional manufacturing and electronics, is worsening rapidly.

Using findings from latest research, the research highlights another noteworthy branch of temporary workers, foreign contract workers. They are found to be complementary to Taiwan's domestic professional and managerial workers, but compete with Taiwan domestic low-skilled workers in job opportunities. As a result, it is not surprising to see occasional antiimmigration sentiments among the ordinary workers, particularly workers of the low-skilled native-borns and Taiwan indigenous peoples. Although immigration impact of foreign contract worker on the availability of job opportunity and internal migration among native-born low-skilled workers is confirmed, it is still not clear to what extent foreign contract workers compete with workers of Taiwan indigenous workers and their mutual impacts.

In the past two decades, growing inequalities developed from many dimensions are becoming one of many global challenges. Likewise, Taiwan is no exception as its economy is highly integrated with global systems. Strong calls from Taiwan employers requesting employment flexibility gained policy support. Nevertheless, employment flexibility has led to two outcomes: (1) the decline of middle- and smallsized enterprises, and (2) the rising power of business monopsony. Nevertheless, labor unions on the other hand are mostly manipulated by employers and thus have very tiny power in affecting Taiwan labor market such as the ability to demand for employment security. Thus, development toward monopsony business only increases the power of employers in shaping labor relations and labor market conditions, and thus the ability to employ who they want to employ. These lead to the formation of contemporary labor market segmentations and labor marginalization that in turn lead to undesirable developments such as growing incomes inequality, stagnation of nominal wage growth, declining real wage level adjusted by CPI and labor productivity, stagnated labor mobility from secondary to primary labor market, etc.

As a result, not only do rising temporary workers and labor marginalization are polarizing its labor market and entrapping marginal labor in secondary labor market, but growing foreign contract workers who are entrapped in secondary labor market too are associated with enhancing segmentation effect in the labor market. Tensions rises sharply in secondary labor market among temporary labor, foreign contract labor, and long-term marginalized TIPs workers. Because of the mechanism of upward mobility from secondary to primary labor market is much weakened due to various dimensions as well as gradual disappearing middle class, workers in primary labor market and the "elites" are enjoying much more fruits of new labor market development as opposed to those in secondary labor market.

In the end, the feelings of relative deprivation among workers in secondary labor market rise sharply in the past ten years. It is thus not surprising to see overwhelming outbreaks of massive social movements appealing for socioeconomic equality and justice in the past three years, with the Sunflower Movement in 2014 being the most noteworthy. Triggers behind increasing social movements in Taiwan resemble those seen in America, European countries, as well as Hong Kong. The author personally thus tends to conclude that, social media and mobile devices are consolidating the degree of cohesion for workers in secondary labor market. The demands from workers of secondary labor market can no longer be ignored by policy makers and employers, because contemporary labor market segmentation and labor relations developed in the past two decades no longer works in the near future. Profound and insightful institutional changes in labor market are urgently required.

\section{NOTES}

1. KMT, or Chinese Nationalist Party, was the ruling party of Republic of China on mainland China in 1912-1949. After World War II, Taiwan political regime was transferred from Japan to Republic of China. KMT was defeated by Chinese Communist Party and moved to Taiwan in 1949. For reference, see Wikipedia at https:// en.wikipedia.org/wiki/Kuomintang.
2. The Taiwanese indigenous population of 530,277 only takes up about $2 \%$ of the whole population of the island, while the Han Chinese constitutes the majority up to about $98 \%$.This estimated figure is from the census of 06/2013 published by the Council of the Indigenous Peoples, Executive Yuan, Taiwan (R.O.C.).
3. ASEAN was established in 1967 in Bangkok by the five original member countries: Indonesia, Malaysia, Philippines, Singapore, and Thailand. Brunei Darussalam joined in 1984, Vietnam in 1995, Laos and Myanmar in 1997, and Cambodia in 1999. For details, see www.asean.org. 


\section{REFERENCES}

Auer, P. and Cazes, S. (2003). Employment Stability in an Age of Flexibility: Evidence from Industrialized Countries. Geneva: International Labour Office.

Bauder, H. (2001). Culture in the labor market: segmentation theory and perspectives of place. Progress in Human Geography, 25, 1, pp. 37-52. http://dx.doi. org/10.1191/030913201672119762

Blust, A. R. (1985). The Austronesian homeland: a linguistic perspective. Asian Perspectives, 26, 1, pp. 45-67.

Brown, C., Haltiwanger, J. and Lane, J. (2006). Economic Turbulence: Is a Volatile Economy Good for America? Chicago: University of Chicago Press. http://dx.doi.org/10.7208/chicago/9780226076348.001.0001

Chang, I. H, Lin, J. P., Liu, C. C. (2010). Migration and transition of socioeconomic status among Taiwan Indigenous Peoples. In Huang, S. M. and Chang, I. H. (eds.) Taiwan Indigenous Peoples: Contemporary Status and Prospect. Taipei: Academia Sinica Press, pp. 51-120.

De Cuyper, N., De Jong, J., De Witte, H. Isaksson, K., Rigotti, T. and Schalk, R. (2008). Literature review of theory and research on the psychological impact of temporary employment: towards a conceptual model. International Journal of Management Reviews, 10, 1, pp. 25-51. http://dx.doi.org/10.1111/j.14682370.2007.00221.x

De Wile, H. (2005). Job insecurity: review of the international literature on definitions, prevalence, antecedents and consequences, SA Journal of Industrial Psychology, 31, 4, pp. 1-6.

Doeringer, P. and Piore, M. J. (197I). Interna Labor Market and Manpower Analysis. Lexington, MA: Lexington Books.

Feldman, D. C., Doerpinghaus, H. I. and Tumley, W. H. (1994). Managing temporary workers: a permanent HRM challenge. Organizational Dynamics, 23, pp. 49-63. http://dx.doi. org/10.1016/0090-2616(94)90068-X

Gordon, D. M., Richard, C. E. and Reich, M. (1982). Segmented Work, Divided Workers: the Historical Transformation of Labour in the United States. Cambridge: Cambridge University Press.
Li, P.J.-K. (2011). The Formosan Tribes and Migration [in Chines]. Taipei: Avanguard Publishing House.

Liaw, Kao-Li, Lin, Ji-Ping and Liu, Chen-Chia (2011). Reproductive contributions of Taiwan's foreign wives from the top five source countries. Demographic Research, 24, 26, pp. 633-670.

Lin, Ji-Ping (2005). A critical review on the issues associated with population and labor migrations in Taiwan, 1980-2000. Journal of Taiwan Sociology, 34, pp. 147-209.

Lin, Ji-Ping (2007). Involuntary Job Turnover in Taiwan, 1996-2000. In Lee, J. S. (ed.) The Labour Market and Economic Development of Taiwan, MA: Edward Elgar, pp. 211-237.

Lin, Ji-Ping (2008). Determinants of socioeconomic inequalities on enrolment of Taiwan national health insurance. Social Policy \& Social Work, 12, 2, pp. 91-122.

Lin, Ji-Ping and Liaw, Kao-Lee (2011). Migrations of the unemployed and reemployment: evidence of primary, return, and onward migrations from Taiwan. Journal of Population Studies, 42, pp. 1-41.

Lin, Ji-Ping (2012). Tradition and Progress: Taiwan's Evolution Migration Reality 2012. Migration Information Source. Washington D.C.: Migration Policy Institute. Available from http://www.migrationinformation.org/Profiles/display. $\mathrm{cfm}$ ?id=877.

Lin, Ji-Ping (2013a). Casual Employment. In Alex, M. (ed.) Encyclopedia of Quality of Life Research. New York: Springer.

Lin, Ji-Ping. (2013b). Are Native "Flights" from Immigration "Port of Entry" Pushed by Immigrants?: Evidence from Taiwan. In Fong, Chiang, E. N. and Denton, N. (eds.) Immigrant Adaptation in Multiethnic Societies - Canada, Taiwan, and the United States. New York, London: Routledge.

Liu, Dorinda Tsai-Hsiu, Chang, Ying-Hwa, Jen-Kuei Li, Paul and Lin, Ji-Ping (2015). Language shift of Taiwan's indigenous peoples: A case study of Kankanavu and Saaroa. Journal of Multilingual and Multicultural Development, 36, 7, pp. 729-749. Available from: http://www. tandfonline.com/loi/rmmm20. http:// dx.doi.org/10.1080/01434632.2015.10 22179

Manning, A. (2003). Monopsony in Motion. Princeton, NJ: Princeton University Press.

Osberg, L., Mazany, R. L., Apostle, R. and Clairmont, D. (1986). Job mobility, wage determination and market segmentation in the presence of sample selection bias. Canadian Journal of Economics, 19, 2, pp. 319-346. http://dx.doi. org/10.2307/135288

Ranis, G. (1992). Taiwan: From Developing to Mature Economy. Boulder, CO: Westview Press.

Reich, M. (ed.) (2009). Segmented Labor Markets and Labor Mobility. Edward Elgar Pub.

Reich, M., Gordon, D. M. and Edwards, R. C. (1973). Dual labor markets: a theory of labor market segmentation. American Economic Review 63, 2, pp. 359-365.

Sassen, S. (1990).The Mobility of Labor and Capital: A Study in International Investment and Labor Flow. Cambridge University Press.

Sen, A. (2004). Capability and well-being. In Nussbaum, M. and Sen, A. The Quality of Life, New York: Routledge, pp. 30-53.

Taubman, P. and Wachter, M. (1986). Segmented labor markets. In Ashenfelter, O. and Layard, R. (eds). Handbook of Labor Economics. New York: North-Holland, pp. 1183-1217.

Tsai, Pan-Lung and Tsay, Chin-Lung (2004). Foreign direct investment and international labour migration in economic development: Indonesia, Malaysia, Philippines and Thailand. In Ananta, A. and Arifin, E. N. (eds) International Migration in Southeast Asia. Singapore: Institute of Southeast Asian Studies, pp. 94-136.

Tseng, Yen-Feng (2004). Politics of importing foreigners: foreign labour policy in Taiwan. In Entzinger, H. Martiniello, M. and Wihtol, C. (eds.) In Migration Between States and Markets. Burlington, VT: Ashgate Publishing Company, pp. 100-118. 